\title{
Research on the Quality of Tax Service and the Efficiency of Tax Collection and Administration - Using Aksu as an Example
}

\author{
Wang Qian, Li Qing \\ College of Economic and Management, Tarim University, Alar, Xinjiang 843300
}

Keywords: tax services; efficiency of collection and administration; countermeasures

\begin{abstract}
With the continuous expansion of tax payment scale in China, tax revenues have been greatly improved. And people in Aksu area have also greatly enhanced their awareness of tax payment in recent years with continuous development of economy, although there are still many problems in the tax service affecting the collection efficiency of tax in Aksu. As the base of the system of tax collection and administration, tax services have obviously influence on the efficiency of collection and administration. Therefore, in this paper, I have conducted research mainly on the tax service quality and efficiency of tax collection and administration in Aksu, hoping to further improve the quality of tax services in Aksu, improve the efficiency of tax collection and promote the rapid development of economy in Xinjiang through this study.
\end{abstract}

\section{Introduction}

As the tax is the main source of income of public finance in China, improvement of the tax service quality and efficiency concerns the taxpayer's compliance with the tax law and also directly affects the quality and efficiency of tax collection and administration. However, in small cities weak in the understanding of tax, there is low tax service quality index and tax collection and administration efficiency. In this case, the tax authority must raise awareness of tax services to provide quality and efficient services for taxpayers.

\section{Countermeasures and suggestions on improvement of tax service quality}

First, improve the hard environment facilities. Tax authorities at the grass-roots level should be equipped with the advanced modern collection and management information system and tax service facilities necessary for providing promotional materials of the tax law and tax guidance for taxpayers, besides capacious and neat multi-functional tax service offices that can meet the needs of daily collection. Second, optimize the soft environmental construction. The focus is one-stop service at the tax service hall, fully realizing that all taxpayers' tax-related affairs are accepted in one tax service hall and many tax matters are handled at one window, so that the taxpayers won't go to many place or have to wait for a long time for the business. It is required to strengthen the publicity of the tax law and tax guidance to help taxpayers have the knowledge of the tax law and know tax affairs.

First, put the taxpayers at the focus of attention. Tax authorities should carefully analyze the needs of taxpayers in accordance with the service philosophy of 'service first and taxpayers supremacy", to ensure that the taxpayers' reasonable needs and expectations are met with the purpose of satisfying the taxpayer under the precondition of law-based tax administration. Second, safeguard the legitimate rights and interests of taxpayers. To safeguard the legitimate rights and interests of taxpayers is the basis of tax services, also the legitimate rights and interests of taxpayers and the duty of tax authorities provided by the Law on the Administration of Tax Collection and its implementing rules. Therefore, the tax authorities must safeguard taxpayers' rights of tax refund deduction and exemption, right to know, right to keep confidential and right of supervision in accordance with the law. To provide the above services through the tax authorities helps to safeguard the 
legitimate rights and interests of taxpayers, thus improving the taxpayer's compliance with the tax law and their consciousness of paying tax in accordance with the law. Second, strive to reduce the tax payment cost. It is required to carefully clean up and standardize administrative fees, provide policy advice, business training and tax law publicity materials for the taxpayers for free. Various tax returns, electronic reporting software and other materials should be provided for taxpayer, truly reducing the burden of taxpayers. Diversification of tax declaration and payment modes should be actively pushed forward, to provide free online declaration service for taxpayers.

First, the tax authorities must seriously carry out tax assessment and develop a plan for the assessment work. Tax authorities at the grass-roots level should develop a plan for the assessment work according to their jurisdictions, number of taxpayers under their jurisdictions and other actualities, to perform assessment and analysis at least once a year with focus on key taxpayers as well as those declare tax at zero or negative rate. The assessments of all taxes declared by the same taxpayer should be combined subject to a centralized plan, avoiding repeated assessments. Tax authorities should invite taxpayers for tax guidance. In case of any puzzle found in analysis and comparison of tax declaration documents provided by a taxpayer, tax authorities need to invite the taxpayer to the tax authority for an interview to explain the tax-related suspects. Invitation for tax guidance is an opportunity for equal exchanges and communications between tax authorities and taxpayer, and also a chance for tax authorities to carry out the policy publicity and tax guidance. Special attention should be paid to the assessment results. For general problem found in tax assessment such as accounting or filling error, policy and program comprehending deviation, as well as existing puzzles, if the facts are clearly ascertained by interviewing, presenting evidence and verifying through investigation and there is no suspected tax evasion or other illegal act, taxpayers can be required to correct by themselves. If taxpayers are required to provide further tax information, correct declaration, pay overdue tax bills or adjust the accounts by themselves, tax authorities should help guide taxpayers to implement item by item according to the tax law. It is necessary to actively carry out tax credit rating.

First, the modern network tax service should be employed. With vigorous development of networking taxation, online declaration, tax payment, certification and invoicing have effectively broaden the channels of taxation for taxpayers, improved the work efficiency of the tax authorities, reduced the tax cost of taxpayers and improved taxpayers' satisfaction and compliance. besides, mobile tax terminal services realized by means of smartphones, tablet computers and other mobile devices are provided in the form of mobile handheld tax bureau, covering tax-related queries, tax declaration and payment, policy push, open taxation and collection encyclopedia, etc., to provide convenience for taxpayers. Second, provide self-help tax terminal services. As a brand new tax service mode, the taxpayer self-service machine can realize integrated disposal of invoice certification, IC tax declaration, tax declaration, invoice verification involved in tax authorities as well as consultation of tax business enterprises and other items, which improves the work efficiency of the tax system and effectively alleviates the waiting pressure of the taxpayers in the tax peak, thus improving the tax service quality. Third, state and local tax bureaus should work jointly to provide tax services. According to the arrangements made by provincial and municipal tax authorities, state and local tax bureaus in Aksu join together to provide unified tax services, so that it is convenient for taxpayers to handle the business of two departments at the same hall, truly easing the burden on taxpayers. And the move helps strengthen tax collection and management, reduce non-levied and non-administrated taxpayers from the head stream, to improve the efficiency of the tax authorities. Fourth, provide universal services in the same city. Tax authorities should provide tax services that are subject to no regional restrictions of the competent tax authority through the tax service hall, self-service machine or other channels. Taxpayers had to go to the competent tax authority for taxrelated business in accordance with the principle of dependency administration in the past. However, in fact operations across the region are very common, especially for the part-time accountants, all individual tax services should be provided in the same city.

First, vigorously promote one-stop service. For tax-related business that the taxpayers apply for, one-stop service should be provided in accordance with the principle of "acceptance at the window, 
interior circulation and completion in time", except the business accepted through the self-service machine and the Internet. It truly realizes integrated window service management, making the tax service hall at the grass-roots branches both the starting point and the ending point for taxpayers to handle tax business, so that all matters can be handled centrally and the problems of multiple management of a single tax-related matter and "repeated visit" of taxpayers, thus saving taxpayers' time cost, transaction cost, psychological cost while providing convenience for vast taxpayers. Second, forward approval authority and provide "handling before approval" tax services. That is, tax-related business that has been recognized should be handled first before approval by forwarding approval authority and adjusting the department functions, to solve the problem of low efficiency of multiple-level examination and approval. The tax-related approval authority of tax authorities at the county level should be forwarded to the tax service hall with approval work in the charge of the tax service window, reducing approval levels and improving the efficiency of approval. Third, simplify the approval process. By returning rights and liabilities to taxpayers, the initiative is given to them. Taxpayers should ensure the documents they provide are legitimate, so as to reduce the data verification time, simplify the approval process and shorten the time limit for examination and approval of tax related matters.

In accordance with the unified requirements of the standards, in daily tax publicity the tax authorities at the county level in Aksu should release and update tax policy documents and their interpretations as well as tax process publicity materials via bulletin boards, electronic display screen in the tax service hall and other channels. Hot issues consulted by taxpayer at a high frequency should be collected and screened, and the replies to them should be submitted to the competent department for approval before release. And the tax service hotline is also an important channel for publicity of taxation. Based on the functions such as call transfer, work order flow, submission of questions, record access and statistics monitoring, a national unified tax consultation handling mechanism should be established for handling tax consulting business by stages, to further expand multiple channels for tax publicity and consultation.

\section{Effect of the tax service quality on the tax collection efficiency}

To improve the tax service, the tax authorities may invest more funds in hardware configuration. The move temporarily increases tax costs of the tax authorities, but in the long run, the work efficiency of the taxation authorities will therefore be greatly improved with effect of cost reduction and resource conservation. In addition, quality tax services greatly cut the cost of tax inspection and punishment, thus significantly lowering the tax costs; from the perspective of reducing the tax cost, the role of tax services is more apparent. If the taxpayer needs to invest must time in collecting necessary tax-related information, the comprehensive information service can help the taxpayers to save cost; simplifying the tax process can reduce psychological and time costs of the taxpayers.

Tax compliance refers that the tax authorities interpret and enforce the law and the taxpayer pay the tax according to their obligations in accordance with the law. According to the classification made by Chinese scholars Ma Guoqiang, tax noncompliance includes ignorance based noncompliance, selfishness based noncompliance and emotionality based noncompliance. The scope of tax collection and administration as well as tax services can be distinguished according to the noncompliance type. For selfishness based noncompliance and emotionality based noncompliance, tax administration should be strengthened with strict law enforcement; for ignorance based noncompliance, the focus is to provide tax services. Occurrence of ignorance based noncompliance arises from construction of service levels of tax authorities due to asymmetric information on tax laws and regulations between taxpayers and tax contractors. Tax authorities can cultivate high tax awareness of people by providing quality tax services, to enable taxpayer to have the full knowledge of the tax law, increase the transparency and decrease information asymmetry between taxpayers and tax contractors, thus promoting tax compliance and increasing tax revenues. 


\section{Conclusion}

As the tax is the main source of income of public finance in China, tax efficiency not only reflects tax service quality of a region but also indicates the tax status of the region. Therefore, in order to improve the efficiency of tax collection, tax authorities should take actions to improve tax service quality practically by optimizing the tax service environment, changing the concept of tax services, innovating tax service means, diversifying tax payment modes, simplifying accessibility and broadening tax consultation channels, to improve the tax collection efficiency across China.

\section{Acknowledgment}

Fund Project: the Supporting Plan for the National Science and Technology: the Integration and Demonstration of the Ecological Rehabilitation and Resource Exploitation and Utilization in South Xinjiang Desert District. (Project No. 2014BAC14B05)

\section{References:}

[1] Xu Jianguo, Zhou Rong. Optimize the Tax Services to Improve the Quality and Efficiency of Tax Collection [J]. Taxation Research, 2005 (11): 96-96.

[2] Shenyang Shenyang Local Taxation Bureau. Research on Present Situation and Countermeasures of Tax Services' Influence on Tax Collection Efficiency [J]. Liaoning Economy, 2016 (10): 1317.

[3] Li Xiaojiao. Research on Tax Services' Influence on Tax Collection and Administration Efficiency [D]. Dongbei University of Finance and Economics, 2015.

[4] Zheng Peng. Research on Tax Services and Optimization of China's Tax Collection and Administration Efficiency [J]. Corporate Culture (every ten days), 2016 (11) : 78-79.

[5] Wang Yu. Research on Fiscal Growth in Aksu Area of Xinjiang [D]. Xi'an University of Technology, 2015. 